\title{
Under what demands land may has actual owner
}

Adamchuk V. ${ }^{1}$, Bulgakov V. ${ }^{2}$, Nadykto V. ${ }^{3}$

${ }^{1}$ National Scientific Centre «Institute for Agricultural Engineering and Electrification» NAAS of Ukraine, 11, Vokzalna Str., Glevakha, Vasilkiv distr., Kiev reg., 08631, Ukraine, ${ }^{2}$ National University of Life and Environmental Sciences of Ukraine, 15, Heroyiv Oborony Str., Kiev, 03041, Ukraine, ${ }^{3}$ Tavria State Agrotechnological Universityx, 18, B. Chmelnitsky Av., Melitipol, Zaporozka oblast., 72310, Ukraine

The purpose. To formulate the basic positions-requirements of the legislative order which adoption will guarantee solution of the question of long-term rent, or even sale of lands of agricultural purpose without negative prospect of reduction in their fertility. Results. They determined five requirements which should get legislative status before opening market of long-term rent (sale) of lands of agricultural purpose. The first requirement concerns a person (physical or legal) - land owner. At the first stage only physical person of Ukraine can be in such role. With grow of experience of managing and achievement of more organic place of Ukraine in European Community it will be expedient to consider and assess desire of foreign persons to become owners of land in Ukraine. The second requirement opens question of price formation for land area. The price should be affordable to the majority of potential players on land market. The third requirement concerns the question of monopoly in possession of land. The essence of this requirement consists in determining the greatest possible land area which can be purchased by one physical person. The problem of professional suitability of potential buyer of land is considered in the fourth requirement. In fact, irrational, inept and negligent managing can lead to catastrophic consequences for all society. Considering that requirement, property right to land is possible to receive only at presence of practical experience and/or potential knowledge in the field of agrarian managing. The fifth, the most important legislative requirement, opens the essence of strict responsibility of land owner concerning the land area. Under condition of non-economic attitude to land, which is offered to be assessed by the level of fertility of soil, the owner of land area should be deprived the right to own land and be financially punished. Conclusions. Under condition of legislative fastening the mentioned five requirements in Ukraine it will be impossible both exclusive, and non-economic possession of land.

Key words: land, proprietor, law, resources, fertility of soil.

https://doi.org/10.31073/agrovisnyk201806-13

In the eternal question of the level of our being, there is the same old reference to poverty. And from the latter to get rid of us is hampered by the habit (sometimes - ignorance) not to be weighed against the objective laws of development of society. Namely, according to our opinion, one of them is now quite spectacularly appearing on the territory of Ukraine. This is a law that relates the direct dependence of the state on the amount of resources it possesses and the rapid development of scientific and technological progress [1].

In fact, the essence of this law lies in the strong dependence of the economy and the budget on the export of one or two varieties of raw materials, which provides a lion's share of state revenue, and therefore, frankly, a country rich in natural resources to scientific and technological progress not configured, and in many cases incapable. And this is really so. After all, when exporting resources, it receives relatively "light" finance, with which it tries to solve if not all, at least most of its problems. The great trouble lies in the consequence that this law generates. The fact is that, when formulating a financial policy based on the "easy" money received, most of the population's needs in goods and services are met by the state at the expense of imports, thereby causing the decline of domestic production. Indeed, why produce something if you can buy someone else. Moreover, this someone else will often be of high quality and widely offered on the market. 
At the same time, destroying its own production, the country begins to depend entirely on imports. At the same time, we do not know or do not understand (or both) that such a state of affairs can be used by someone. There are no friends in business! Sufficient for consumers to reduce the price of a resource, as a country (the owner of this resource) becomes a kind of hostage to the situation.

In order to make sure that the postulate is correct, one should pay attention to Russia. It is the manifestation of the law on resources (and in Russia, it is gas and oil) with a significant (if not exceptional) measure of the effectiveness of sanctions imposed by the western community against the country.

On the basis of the above, a completely understandable question may arise: what about Ukraine? Especially agrarian, which nowadays takes the third place in the export of cereals, 4th - on the sale of corn, 5th - on the sale of sorghum, 7th - on the export of soybeans. In this case, the task is to go on the line of production of 80 and even 100 million tons of grain. Moreover, every third dollar exported to the country's treasury provides agricultural production.

It is difficult to disagree with this, as it is even more difficult to disagree with the fact that the majority of exported foreign currency finance comes from the sale of resources, rather than goods, the actual development of which provides value added and all related, positive moments.

Focusing on an increase in the volume of sales of resources, we have neglected our own processing industry. In Ukraine, which in previous times was marked by its agricultural technical potential, the domestic tractor and combine industry was practically set to the brink of destruction. Having a large number of new and, most importantly, raionized varieties of agricultural crops, we have very little seeds. As for dealing with own production of mineral fertilizers and protection means, I should not speak.

Analyzing the consequences of the manifestation of this window, we want to emphasize that practically the only way to avoid them is the presence of the owner, that is, such a host who would be keen on the economical, economical use of resources (because they are not eternal!) And tried to increase the efficiency of their activities at the expense of the development of the neoprene production with the creation of additional jobs, the expansion of the nomenclature of goods, etc.

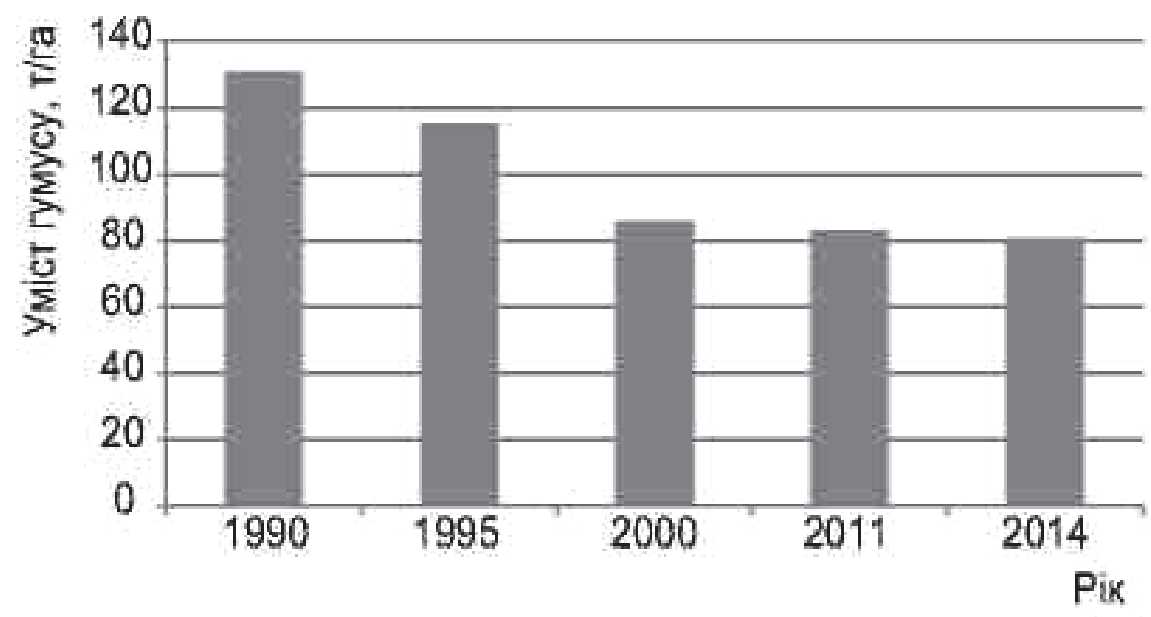

Fig. 1. Dynamics of losses of humus by Ukrainian soils

In other words, we need an efficient and genuine owner, first of all, to land, because it allows us to obtain the corresponding, and now, export resources.

At the same time, such an important question arises: is there now an effective owner in the land, which currently includes the state and tenants? If it is, why in Ukraine we have 10-15 million hectares of degraded soils? The main causes of their degradation are the effects of water (13.3 million hectares) and wind (6 million hectares) erosion, as well as chemical (14 million hectares) and physical (12.6 million hectares) degradation [2-5]. If this condition of things is not remedied urgently, then we really will have a high probability of decreasing the arable land area for the country, which is inevitable, while decreasing the population's livelihoods. 
According to data from the National Institute for Strategic Studies based on analytical information, since 1990, the average weighted index of humus content ( $/$ ha) in Ukrainian soils is constantly decreasing [9] (Fig. 1). And the preconditions for the appearance of a qualitatively different (positive) character of this process are not observed yet. Moreover, there is a problem of soil redevelopment in Ukraine of almost 22 million hectares of arable land [10]. In the first place, the running systems used by mobile power industry operators. Although there are plenty of scientific advice on how to improve this situation, in practice they are not widely used. In the subconsumption, the equilibrium density of soils in Ukraine is gradually increasing. And this, in turn, tends to reduce gumus in the soil (Fig. 2).

Despite all the doubts, one of the effective, in our opinion, ways of solving the above problem is the transfer of land to the hands of the true owner. And this means that it can be an object of ownership.

Today, in Ukraine, this problematic issue is widely declared in the form of a banal dilemma: "to sell - not to sell". Most supporters of the first direction, referring to Art. 14 of the Constitution of Ukraine and the relevant articles of the Land Code of Ukraine, are not so much interested in how much the sale of land demands. Their position can be formulated in the words of one of the heads of the farm: "The land market is not to be afraid. It is enough for us to "play" with the question of lifting the moratorium "(see The Ukrainian Farmer, October 2017). At the same time, the underlying moment is the call to remember that "... the tenant is not the owner, and he is not interested in developing the land, cultivating it, restoring it".

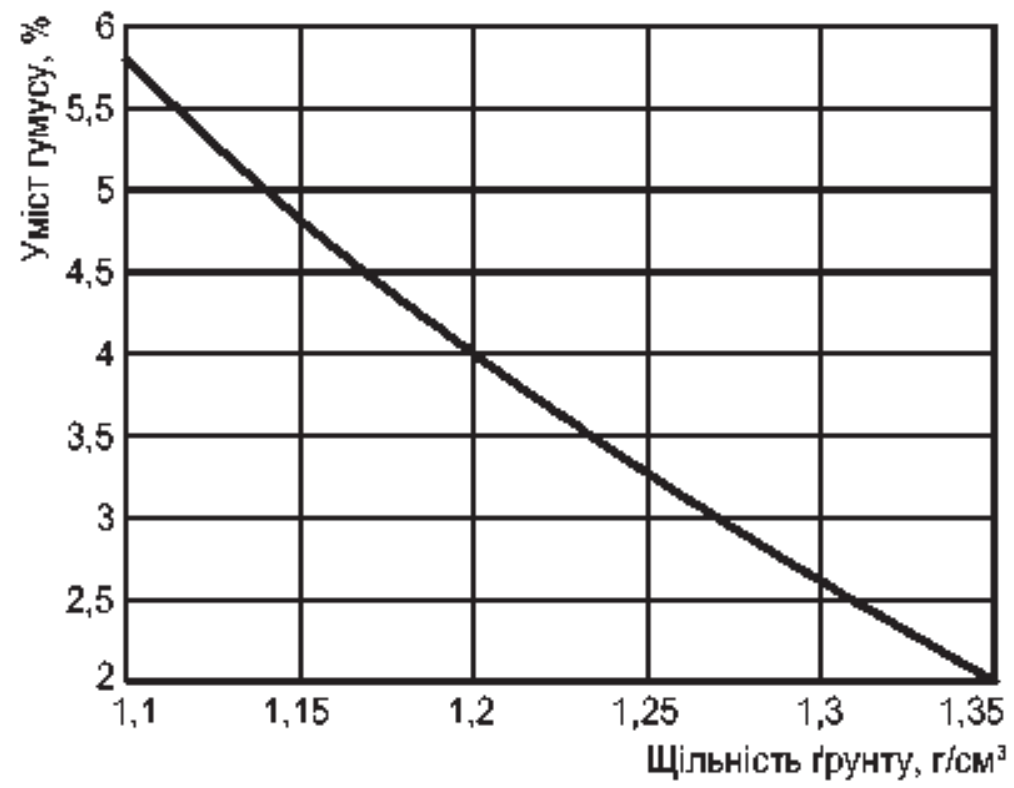

Fig. 2. The trend of reducing humus in the soil with increasing its density [11]

Orthodox adherents of another way (ie, refusal to sell land) can also be divided into two camps. Representatives of the first of them do not want to hear about any conditions: do not sell the land - and the land, otherwise it will buy the oligarchs, etc.

Representatives of the second camp adhere to the view that the opening of the land market if possible, then it should be carried out necessarily in stages $[6,7]$. The first of these should include the sale of agricultural land of state and communal property, as well as inherited land shares for a normative monetary valuation. At the second stage, as MP says Martyniuk, sale and purchase of land should be carried out at the market prices that were formed in the first stage [6]. At the same time, it is necessary to introduce mechanisms for clear tracing of agricultural land and preventing possible risks in the course of transactions with land plots. As for land owners, they should be not only physical (ie citizens of Ukraine), but also legal persons (farms, executive bodies, etc.).

In the opinion of People's Deputy L. Kozačenko, who concentrates on the position of the majority of supporters of the phased solving of the problem under consideration, the following steps should be taken at the first stage. The first - a 10-year moratorium on the purchase of land by legal entities and physical 
persons-foreigners. The second is the limitation of the size of the land plot for one individual with an area of 250-500 ha. The third is the priority for the purchase of land: a resident, tenant, other individuals. The fourth is the organization of the land purchase and sale process. Fifth - a pilot project of land market in one - two regions of the country.

By the way, all these and similar steps of phased solving the problem of the land market supporters of his prohibition consider unconvincing arguments [8].

Discussion of the problem. If we analyze the current state of solving the problem under consideration, then one can notice such a feature. Outside the community's attention was the most important factor: the responsibility of the landowner. Only in several publications it is stated that in principle it should be. At the same time, more or less concrete form (essence) of responsibility is not offered, based on the experience of European countries.

According to our deep conviction, the law-governed condition of responsibility for the use of land is the most important. Moreover, it does not matter - it is privately owned or leased. From the point of view of preserving its fertility - as a kind of guarantor of our food security and overall existence - it does not matter.

Since preservation and further enhancement of the fertility of Ukrainian soils is impossible without an effective owner, it should be created, obviously, also by opening the market of agricultural land. However, in our opinion, this can only be done after the preliminary legalization of the following, at least five mandatory conditions.

Condition first The owner of the land can only be a physical (and not legal!) Personality - it is exclusively a citizen of Ukraine. Now we have to act this way. With the advent of management experience, with the achievement of more organic typing of our country into the European space, etc., it is time to consider and appreciate the desire of foreign physical (and not only) individuals to become owners of land in Ukraine.

A friend's condition Land prices should be affordable for most potential land market players. At the same time, the question is not at all about its depreciation, but that the opportunity to buy land should have not only those whom we now call oligarchs. And for a prohibitively high price, this can happen. Moreover, if we take into account the credit policy that is and, perhaps, will take a long time in our country.

The task of quantifying 1 hectare of land should be the subject of public discussion with the mandatory involvement of the relevant scientists who are in Ukraine. The purpose of the state when opening the land market should be not just how much of the money from its sale, due to the creation of an effective mechanism for the use of its most important natural wealth - land resources of agriculture.

Condition third The impossibility of monopoly possession of land. There is no need to talk about the fatalities of this phenomenon once again. The society has to agree (which is quite real) and at the legislative level to establish the maximum possible area of land that can be purchased by one individual.

Condition fourth. The buyer of the land must have evidence that his at least potential ability to manage on it. Otherwise it is impossible. Why in order to sit behind the wheel of a transport vehicle or take a leading position or even a rank position, the person should get the corresponding rights (proofs), and it is possible to manage the business on the ground without it? As already emphasized above, irrational, impolite, negligent farming on the ground may eventually lead to catastrophic consequences for our entire society.

Such rights (proofs) may be the availability of agrarian education or practical experience in agricultural production in the past. In Ukraine, due to the existing network of agrarian universities, there is no problem in securing appropriate education. Moreover, higher agricultural institutions perfectly have a short-term practice of enhancing professional agricultural qualifications. And this opportunity can now be used by almost everyone.

Condition fifth, the most important. The land is practically the only property with which its owner can not act as he likes. Therefore, first of all, the land should be used exclusively for its purpose, therefore, to give a crop. And this appointment can be changed only in case of force majeure of state significance. Secondly, no one and no one should reduce the fertility of the soil. According to DSTU, "fertility is the ability of the soil to meet the needs of plants in the elements of nutrition, moisture, air, and also provide conditions for their normal livelihoods to create their appropriate biomass (crop)" [12]. It is characterized by numerous indicators and among them the biological parameters of fertility include the content of the soil. 
By the indicator of monitoring (conductivity) of soil conductivity with the accumulative-humus profile [12], for example, we can accept almost all the well-known and understandable level of humus in the soil. In the presence of a modern laboratory base, its practical definition is not the subject of discussion. Another thing is that this figure should be reliably fixed for each land area before implementing its sale procedure.

For example, for example, at some point in a site at the time of purchase, the humus level was $3.8 \pm$ $0.2 \%$. Such a digital representation of this estimator means that it is in the confidence interval of $3.6-4.0 \%$. Otherwise, the level of humus in the soil can not be represented, since the nature of its distribution in the area of the site is a process of exclusively random.

If, after a certain period (year or two, for example), it turns out that the level of humus in the area used is within the confidence interval (in this case it is $3.6-4.0 \%$ ), then the land is exploited by the owner properly.

If the level of soil humus is increased by more than $4 \%$, the owner of this land, as its effective owner, should receive appropriate financial incentives from the state.

At the same time, if, at the time of testing, the humus level of the controlled land area went below the confidence interval, that is, it became less than $3,6 \%$ (for example, $3,4 \%$ ), it should be irrevocably and permanently removed from its owner, and the latter must compensate losses (loss of humus level by $0,2 \%$ ), caused by the land by his "careful" management. Moreover, he is at the legislative level deprived of the right to re-purchase land.

The function of the humus level controller in the receiving land should be assumed by the state. It will be organically combined with its desire to have an effective owner of agricultural land.

\section{Conclusions}

The presence of the abovementioned legislative conditions (and especially the fifth of them) is a prerequisite for the opening of the land market as one of the options for the formation of a careful and efficient owner of the landowner.

It should be remembered that the adoption of a law on the sale of land can not require its mandatory implementation by the current owners of land shares. As it can not cancel the current lease relations. Especially when they satisfy both landlords and tenants.

\section{Bibliography}

1. Shmidt V.A., Hanapina A.E., Kuandyk A.N. Effekt «gollandskoj bolezni» v ekonomike. [The effect of "Dutch disease" in the economy ]. URL [http://www.konspekt.biz]. [in Russian].

2. Baliuk S.A., Medvediev V.V., Tarariko O.H. ta in. (2010). Pro stan rodiuchosti gruntiv Ukrainy. [About the state of soil fertility in Ukraine]. Natsionalna dopovid. Kyiv,. 111 p. [in Ukrainian].

3. Baliuk S.A., Medvediev V.V., Vorotyntseva L.I., Shymel V.V. (2017). Suchasni problemy dehradatsii gruntiv i zakhody shchodo dosiahnennia neitralnoho yii rivnia. [Modern problems of soil degradation and measures to achieve its neutral level]. Visnyk ahrarnoi nauky. № 8. P. 5-11. [in Ukrainian].

4. Zaryshniak A.S., Baliuk S.A., Medvediev V.V., Truskavetskyi R.S., Miroshnychenko M.M., Kucher A.V., Momot H.F. (2016). Naukove zabezpechennia upravlinnia gruntovymy resursamy $\mathrm{v}$ konteksti yevrointehratsiinykh protsesiv. [Scientific provision of management of soil resources in the context of European integration processes]. Naukova dopovid. Kharkiv. 44 p. [in Ukrainian].

5. Truskavetskyi R.S., Tsapko Yu.L. (2016). Osnovy upravlinnia rodiuchistiu gruntiv. [Fundamentals of soil fertility management ]. Kharkiv. 388 p. [in Ukrainian].

6. Martyniuk M.P. (2017). Rynok zemel silskohospodarskoho pryznachennia v Ukraini: stan ta perspektyvy zaprovadzhennia. [The market of agricultural lands in Ukraine: the state and prospects of implementation]. Ekonomika APK. № 3. P. 15-21. [in Ukrainian].

7. Lupenko Yu.O., Khodakivska O.V. (2016). Naukovi zasady zaprovadzhennia rynkovoho obihu zemel. [Scientific principles of introduction of market circulation of land. scientific report]. Naukova dopovid. Kyiv: NNTs «IAE».40 p. [in Ukrainian].

8. Koliubakin V. (2017). Arhumenty, shcho ne perekonuiut. [Arguments that do not convince].The Ukrainian Farmer. № 9. P. 56-58. [in Ukrainian]. 
9. Hreshchuk H.I. (2017). Ekoloho-ekonomichni naslidky transformatsii zemelnykh vidnosyn u silskomu hospodarstvi. [Ecological and economic consequences of the transformation of land relations in agriculture.]. Zbalansovane pryrodokorystuvannia. № 2. P. 108-114. [in Ukrainian].

10. Baliuk S.A. Medvediev V.V., Miroshnychenko M.M., Skrylnyk Ye.V., Tymchenko D.O., Fatieiev A.I, Khrystenko A.O., Tsapko Yu.L. (2012). Ekolohichnyi stan gruntiv Ukrainy. [Ecological condition of soils of Ukraine]. Ukrainskyi heohrafichnyi zhurnal. № 2. P. 38-42. [in Ukrainian].

11. Aulin V.V. Stan samoorhanizatsii seredovyshcha gruntu ta zakonomirnosti znosu robochykh orhaniv gruntoobrobnykh mashyn. [The state of self-organization of the soil environment and the patterns of wear of working bodies of soil-working machines]. Problems of Tribolodgy. 2013. № 1. P. 114-118. [in Ukrainian].

12. Polupan M.I., Velychko V.A., Solovei V.V. (Polupan M.I. Ed). (2015). Rozvytok ukrainskoho ahronomichnoho gruntoznavstva: henetychni ta vyrobnychi aspekty. [Development of Ukrainian Agronomy Soil Science: Genetic and Production Aspects]. Kyiv: Ahrarna nauka. 400 p. [in Ukrainian]. 